\title{
Social Environmental Support Towards Leisure Time Activities Among Multi-Ethnic Youth in Malaysia
}

\author{
Nurul Hidayati Hamid ${ }^{1}$, Abdul Razaq Bin Ahmad ${ }^{2} \&$ Mohd Mahzan Awang ${ }^{3}$ \\ ${ }^{123}$ Faculty of Education, The National University of Malaysia, MALAYSIA \\ E-mail: hidayati242@gmail.com
}

\begin{abstract}
The purpose of this study was to identify the aspects of social environmental support includes family support, peer support and local community support towards leisure activities multiethnic youth in Malaysia. Social environmental support for this study is based on Bronfenbrenner's ecological system theory. The study was conducted in the form of survey which uses questionnaire that involved 1184 youths from multiple ethnics which are Malay, Chinese and Indian. The overall findings of the study showed that social environmental support is at moderate high level. Therefore, various programs need to be planned well in order to encourage youth participation in leisure activities.
\end{abstract}

Keywords: Social environmental support, family support, peer support, local community support, ecological system, leisure activities

\section{Introduction}

Researchers has indicated that leisure activities have been associated with various benefits including better social relationships, health, enhances knowledge, skills and wellbeing of individuals, families, communities, and societies (Aman, 2005; Brajša-Žganec, 2011; Trenberth, 2005)(BrajšaŽganec et al. 2011). Leisure is a powerful context and becomes important to youth in which development may happen during their leisure activities (Caldwell, 2008). For this reason, social environmental support from family, peers and the local community should be conducted in order to increase their participation in leisure activities.
Youth refers to a transitional stage from the dependence of childhood to adulthood's independence (UNESCO 2014). When they become young-adult, they begin to have the autonomy to choose any leisure activities. During the transition, youth may facing many change and challenges as they moved into adult life. Therefore, participation in leisure activities will helps youth to socialise in a successful manner (Shin \& You, 2017).

Participation in leisure activities is considered as part of the learning process in which individuals can find the identity of themselves, increase knowledge about the sociocultural environment and to practice social skills. Mohd Sham (2014) states the choice of leisure activities and lifestyle have an influence on the success of the transition 
from youth to adulthood. The initial stage of youth is a time of much confusion. At this stage of youth undergoing a process of change from adolescence to adulthood and this change affects them (Chen, TS, and Sutan, 2013). The youth need a conducive social environment to the develop a positive self-forming (Taylor, Oberle, Durlak, \& Weissberg, 2017). A weak support of social environment can disrupt the lives of youth. This is because a weak social support influences the behavior of youth

The development of an individual is closely related to the surrounding of the individual. According to Bronfenbrenner (1989) human development and behavior involves the interaction between the individual and the environment. The development of every human being is different due to the different environments in which the individual resides. Social environment support often occur in the context of stable social relationships that are close to the subject such as family members, friends and local communities. All of these factors provide a strong influence in the use of leisure time activities of youth in Malaysia. Social environment support in this study refers to the Ecological Systems Theory by (Bronfenbrenner, 1989) in which human development occurs in a social system that relate to each other.

This theory describes the five types of environments that affect the lives of the youth that are microsystem, mesosystem, ecosystems, macrosystem and chronosystem. This study will only touch two layers in Theoretical Ecology which is the microsystem layer and ecosystem layer. Microsystem is the closest environment that interacts directly with individuals. Through microsystem environment, social life at home and in the community greatly influence the formation of social behaviour among youth. Ecosystem is refers to the factor that help to influence people to be active in their leisure time activities via indirect interaction. Ecosystem is a system that involves the external environment in which youth plays no active role but their development is influenced by the actions of the members in this ecosystem through the experiences that pass. This review is based on the assumption that the support of the social environment, represented by family support, peer support and the support of the local community will affect the youth perspective on leisure activities.

\section{Methodology}

In conducting this study, a survey involving quantitative methods was used to answer the question by using the questionnaire instrument modified from previous studies. The study was conducted among youth of different ethnic groups in Malaysia. The sample involved 1184 respondents that consisted of youth aged between 19 to 25 years who are ethnic Malay, Chinese and Indian. This study used a questionnaire that are filled out by the respondents itself to explore the support of the family, peers and community.

\section{Findings and Discussion}

Table 1: Descriptive statistic of social environment support

\begin{tabular}{lc}
\hline Social Environment Support & Mean \\
\hline Family support & 4.01 (High) \\
Peers support & 3.91 (Moderate high) \\
Local community support & 3.83 (Moderate high) \\
Total & $\mathbf{3 . 9 2}$ (Moderate high) \\
\hline
\end{tabular}

The findings indicate that social environment support for family, peer and community support for Malaysian youths were moderately high. The study found that the family support youth to participate in religious activities and engage in educational activities. Participation in religious and educational activities is a support that is happen to be a solution to the problem of spiritual education that seemed to be more severe and very hard to see on in kids nowadays (Irma, Norlizah \& Fathiyah 2017). The participation is capable of shaping the child's personal attitudes and to motivate and inspire them to become more successful in their life. The results of this study support the findings by Stapa Zakaria Ahmad Munawar Ismail \& Noranizah Joseph (2012) that explained the support of parents indicate significant value towards positive development of the student by providing guidance, instruction, encouragement and support in learning to develop soft skills of the student. In addition, parents not only provide resources and learning purposes but indirectly involved in the learning process.

The results also showed that peers have the same support to encourage youth to participate in family and religious activities. This means that the peer influence is the most powerful resource in self-development, changing values and attitudes of adolescents when the influence of parents and family fell in early adolescence (Anisa Saleha 2015). Peer influence on the formation of personality focuses a lot on the negative effect, but the fact that peers have always been a group that is closest to the youth itself should be consider in the design of programs to enable peers to make positive contributions towards the establishment character and morals among them (Azhar, 2006). Interaction with peers will affect the development of the intellectual development of students, personality, emotions, social and moral development of students in the school (Stapa Zakaria 
et al. 2012). This mean that peer among the youth has an admirable character to absorb the positive values.

Local community provides facilities to promote religious activities and organize activities that involve family members. Not to differ much with parents and peers, local communities also provide support towards religious activities. Local community in different level had organize various religious activities either held formally or informally. Involvement in the community can help to promote tolerance among the youth of various ethnic groups in Malaysia. This statement is in line with Hagar and Harris (2005), which states all the characteristics of the community have a critical impact on the treatment of community members, especially the younger members. In addition to relationship pattern that exists between youth with other members in their residential community, social and environmental conditions of the residential community also influence attitudes and behaviours. In short, residential community has a significant role in shaping the social behaviour of its members.

\section{Conclusion}

In conclusion, the support of the social environment, especially family, friends and the local community plays an important role in the involvement of youth in his spare time. Therefore, the responsibility for the family, friends and local communities is to improve and control the use of leisure time among the youth such as encourage them to participate in a program or to improve knowledge in the non-formal event, participate in sports and traditional recreational, volunteered in spiritual and religious related activities, participate in various family activities, and participate in various community programs and courses related to business and entrepreneurship.

\section{References}

[1] Azhar Ahmad. 2006. Strategi Pembelajaran Pengaturan Kendiri Pendidikan Islam dan Penghayatan Akhlak Pelajar Sekolah Menengah di Sarawak. Tesis Dr. Falsafah. Bangi: UKM.

[2] Aman, M. S. (2005). Leisure Policy In New Zealand And Mala Ysia : A Comparative Study Of Developments In.

[3] Anisa Saleha. 2015. Keterlibatan, sokongan pembelajaran dan pencapaian pelajar berdasarkan gender peringkat persekolahan dan lokasi. Tesis Dr. Fal, Fakulti Pendidikan, Universiti Kebangsaan Malaysia.

[4] Brajša-Žganec, A., Merkaš, M., \& Šverko, I. (2011). Quality Of Life And Leisure Activities: How Do Leisure Activities Contribute To Subjective Well-Being? Social Indicators Research, 102(1), 81-91. Https://Doi.Org/10.1007/S11205-010-9724-2

[5] Bronfenbrenner, U. (1989). Ecological Systems Theory. Annals Of Child Development, 6, 187-249.
[6] Caldwell, L. L. (2008). Adolescent Development Through Leisure: A Global Perspective. World Leisure Journal, 50(1), 3-17.

[7] Chen, T. S., \& Sutan, R. (2013). Faktor-Faktor Sokongan Sosial Yang Mempengaruhi Penghargaan Kendiri Remaja Sekolah Menengah Daerah Melaka Tengah. 8(434), 20-29.

[8] Irma Yanti Mahamud, Morlizah Che Hassan \& Fathiyah Mohd Fakhruddin. 2017. Penglibatan Ibu Bapa Dalam Aktiviti Pembelajaran Anak Di Rumah Dan Hubungannya Dengan Pencapaian Akademik Murid Sekolah Agama Bantuan Kerajaan (SABK). Jurnal Pendidikan dan Inovasi, 5(1): 42-62.

[9] Mohd Sham, M. R. (2014). Aspirasi Kepimpinan Belia. $1-8$.

[10] Shin, K., \& You, S. (2017). Leisure Type, Leisure Satisfaction And Adolescents' Psychological Wellbeing. 7(2), 53-62. Https://Doi.Org/10.1017/Prp.2013.6

[11] Siti Hajar Abu Bakar Ah \& Haris Abdul Wahab. 2005. Komuniti Kediaman Dan Salah Laku Antisosial Di Kalangan Kanak·Kanak Melayu. Jurnal Pengajian Melayu, 16: 292-312.

[12] Taylor, R. D., Oberle, E., Durlak, J. A., \& Weissberg, R. P. (2017). Promoting Positive Youth Development Through School-Based Social And Emotional Learning Interventions: A Meta-Analysis Of Follow-Up Effects. Child Development, 88(4), 1156-1171. Https://Doi.Org/10.1111/Cdev.12864

[13] Trenberth, L. (2005). The Role, Nature And Purpose Of Leisure And Its Contribution To Individual Development And Well-Being. British Journal of Guidance \& Counselling, 33(1), 1-6. Https://Doi.Org/10.1080/03069880412331335849

[14] Zakaria Stapa, Ahmad Munawar Ismail \& Noranizah Yusuf. 2012. Faktor persekitaran sosial dan hubungannya dengan pembentukan jati diri. Jurnal Hadhari Special Edition: 155-172. 